University of Nebraska - Lincoln DigitalCommons@University of Nebraska - Lincoln

2014

\title{
A GIS-based vulnerability assessment of brine contamination to aquatic resources from oil and gas development in eastern Sheridan County, Montana
}

Todd M. Preston

USGS Northern Rocky Mountain Science Center, tmpreston@usgs.gov

Tara Chelsey-Preston

USGS Northern Rocky Mountain Science Center, Institute on Ecosystems, tchesleypreston@usgs.gov

Joanna N. Thamke

USGS Montana Water Science Center, jothamke@usgs.gov

Follow this and additional works at: http://digitalcommons.unl.edu/usgsstaffpub

Preston, Todd M.; Chelsey-Preston, Tara; and Thamke, Joanna N., "A GIS-based vulnerability assessment of brine contamination to aquatic resources from oil and gas development in eastern Sheridan County, Montana" (2014). USGS Staff -- Published Research. 842. http:// digitalcommons.unl.edu/usgsstaffpub/842

This Article is brought to you for free and open access by the US Geological Survey at DigitalCommons@University of Nebraska - Lincoln. It has been accepted for inclusion in USGS Staff -- Published Research by an authorized administrator of DigitalCommons@University of Nebraska - Lincoln. 


\title{
A GIS-based vulnerability assessment of brine contamination to aquatic resources from oil and gas development in eastern Sheridan County, Montana
}

\author{
Todd M. Preston $^{\mathrm{a}, *}$, Tara L. Chesley-Preston ${ }^{\mathrm{b}}$, Joanna N. Thamke ${ }^{\mathrm{c}}$ \\ a Parallel Inc., USGS Northern Rocky Mountain Science Center, 2327 University Way Ste. 2, Bozeman, MT 59715-6507, USA \\ b Institute on Ecosystems, USGS Northern Rocky Mountain Science Center, 2327 University Way Ste. 2, Bozeman, MT 59715-6507, USA \\ c USGS Montana Water Science Center, 3162 Bozeman Ave., Helena, MT 59601-6456, USA
}

\section{H I G H L I G H T S}

- Oil extracted from the Williston Basin is often co-produced with highly saline brine.

-We assessed potential brine contamination to aquatic resources from oil development.

- The assessment was based on oil well, geologic, and hydrologic characteristics.

-We analyzed surface and groundwater to determine the magnitude of contamination.

- The assessment did well in predicting sites with high and low levels of contamination.

\section{A R T I C L E I N F O}

\section{Article history:}

Received 26 March 2013

Received in revised form 20 August 2013

Accepted 8 September 2013

Available online 21 December 2013

\section{Keywords:}

Williston Basin

Prairie Pothole Region

Energy development

Vulnerability assessment

Water quality

Saline contamination

\begin{abstract}
A B S T R A C T
Water (brine) co-produced with oil in the Williston Basin is some of the most saline in the nation. The Prairie Pothole Region (PPR), characterized by glacial sediments and numerous wetlands, covers the northern and eastern portion of the Williston Basin. Sheridan County, Montana, lies within the PPR and has a documented history of brine contamination. Surface water and shallow groundwater in the PPR are saline and sulfate dominated while the deeper brines are much more saline and chloride dominated. A Contamination Index (CI), defined as the ratio of chloride concentration to specific conductance in a water sample, was developed by the Montana Bureau of Mines and Geology to delineate the magnitude of brine contamination in Sheridan County. Values $>0.035$ indicate contamination.

Recently, the U.S. Geological Survey completed a county level geographic information system (GIS)-based vulnerability assessment of brine contamination to aquatic resources in the PPR of the Williston Basin based on the age and density of oil wells, number of wetlands, and stream length per county. To validate and better define this assessment, a similar approach was applied in eastern Sheridan County at a greater level of detail (the $2.59 \mathrm{~km}^{2}$ Public Land Survey System section grid) and included surficial geology. Vulnerability assessment scores were calculated for the 780 modeled sections and these scores were divided into ten equal interval bins representing similar probabilities of contamination. Two surface water and two groundwater samples were collected from the section with the greatest acreage of Federal land in each bin. Nineteen of the forty water samples, and at least one water sample from seven of the ten selected sections, had $\mathrm{Cl}$ values indicating contamination. Additionally, $\mathrm{Cl}$ values generally increased with increasing vulnerability assessment score, with a stronger correlation for groundwater samples $\left(R^{2}=0.78\right)$ than surface water samples $\left(R^{2}=0.53\right)$.
\end{abstract}

(c) 2013 Elsevier B.V. All rights reserved.
Abbreviations: CI, Contamination Index (ratio of chloride ( $\mathrm{mg} / \mathrm{L}$ ) to specific conductance $(\mu \mathrm{S} / \mathrm{cm}))$; DS, Dissolved Solids; IC, Ion Chromatography; GIS, Geographic Information System; NHD, National Hydrography Dataset; NWI, National Wetlands Inventory Dataset; PLSS, Public Land Survey System; PPR, Prairie Pothole Region; STEPPE, Science Team about Energy in Prairie Pothole Environments; SSURGO, Soil Survey Geographic Database; WPA, Waterfowl Production Area.

* Corresponding author. Tel.: +1 406994 5034; fax: +1 4069946556.

E-mail addresses: tmpreston@usgs.gov (T.M. Preston), tchesleypreston@usgs.gov (T.L. Chesley-Preston), jothamke@usgs.gov (J.N. Thamke).

\section{Introduction}

\subsection{Background}

Oil and gas production from the Williston Basin (Fig. 1) in the Northern Great Plains often produces large quantities of extremely saline coproduced water, or brine (used hereafter), with ratios of 10 barrels of brine to 1 barrel of oil not uncommon (Wanty, 1997). Superimposed over much of the northern and eastern parts of the Williston Basin is 


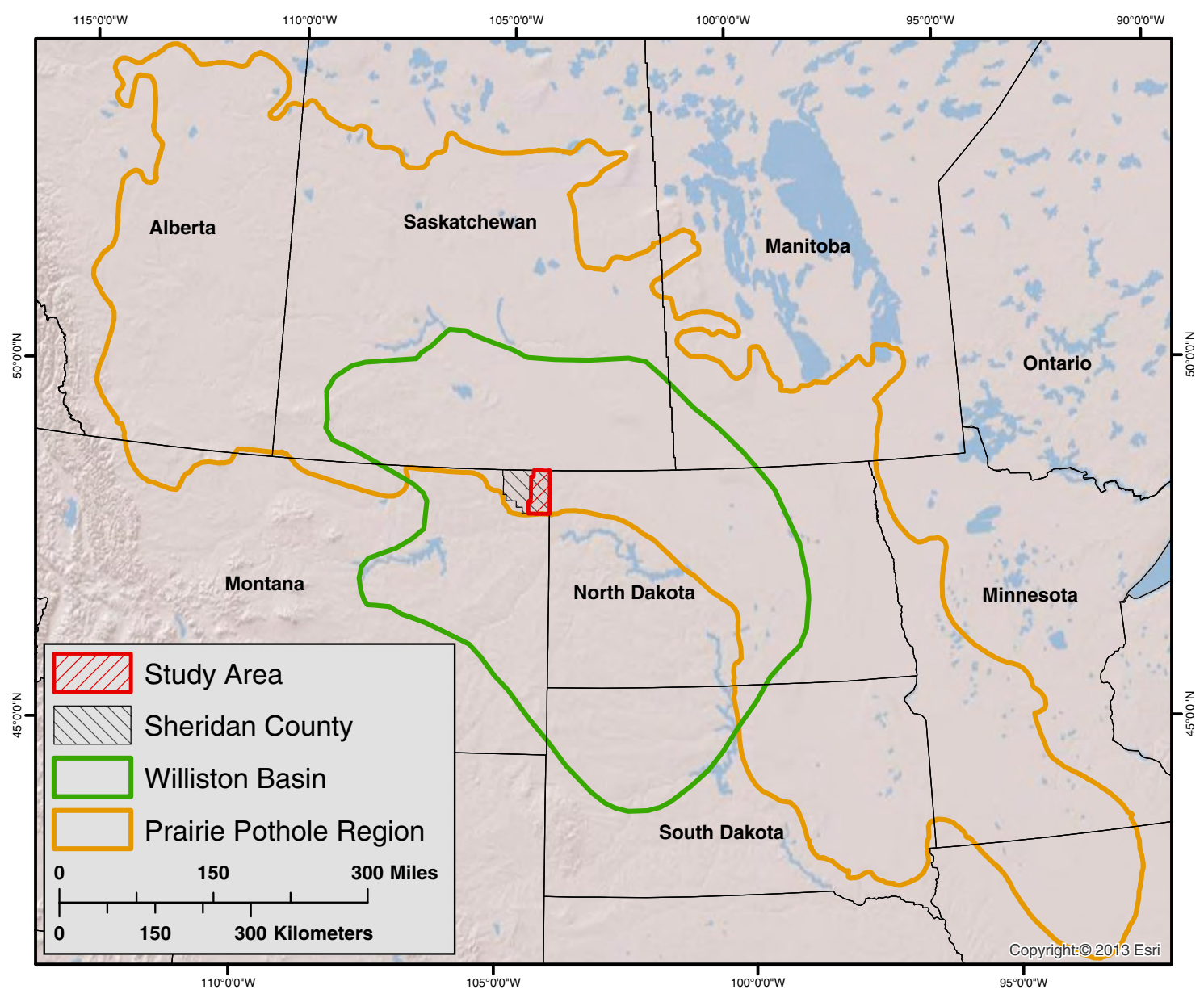

Fig. 1. Map showing the study area, Williston Basin and Prairie Pothole Region.

the Prairie Pothole Region (PPR), which is characterized by glacial deposits and contains millions of wetlands that provide critical habitat for the majority of North American migratory waterfowl (Batt et al., 1989). Previous reports have documented brine contamination to surface water and shallow groundwater resources near oil-field facilities in the Williston Basin and PPR (Murphy, 1983; Murphy and Kehew, 1984; Murphy et al., 1988; Beal et al., 1987; Reiten and Tischmak, 1993; Thamke and Craigg, 1997; Peterman et al., 2010; 2012; Preston, 2011). Eastern Sheridan County, Montana, lies within the PPR of the Williston Basin (Fig. 1) and has a documented history of brine contamination associated with oil and gas production (Reiten and Tischmak, 1993; Preston, 2011; Peterman et al., 2012).

Although the Williston Basin and PPR have surface water and shallow (surficial glacial deposits) groundwater with a wide range of Dissolved Solids (DS) and salinity concentrations, the chemistry is distinctly different than the deep formational groundwater co-produced during oil and gas development. The chemistry of surface water and shallow groundwater is often determined by the hydrologic position in the landscape, with DS and salinity increasing along flowpaths from recharge to discharge areas (Swanson et al., 2003). Surface water and shallow groundwater in recharge areas generally have DS concentrations less than $1000 \mathrm{mg} / \mathrm{L}$ while discharge areas generally have DS concentrations less than $100,000 \mathrm{mg} / \mathrm{L}$, are enriched in sulfate and bicarbonate, and have relatively low chloride concentrations (LaBaugh et al., 1987). In contrast, the deep formational groundwater (brine) generally has much higher DS concentrations and is dominated by chloride. Iampen and Rostron (2000) report an average DS concentration of $300,000 \mathrm{mg} / \mathrm{L}$ from 50 samples of Williston Basin brine.
The stark chemical differences between surface water and shallow groundwater relative to the deep brine allow for identification of brine contamination. Reiten and Tischmak (1993) developed a Contamination Index $(\mathrm{CI})$ to distinguish water resources with naturally high DS and salinity concentrations from water contaminated by brine in eastern Sheridan County, Montana. The $\mathrm{Cl}$ is the ratio of chloride concentration $(\mathrm{mg} / \mathrm{L})$ to specific conductance $(\mu \mathrm{S} / \mathrm{cm})$ of a water sample and allows for field and/or laboratory determination of brine contamination across water chemistries that range from fresh to extremely saline. Additionally, the $\mathrm{CI}$ remains relatively stable in groundwater wells that develop vertical density gradients due to high DS concentrations (Reiten and Tischmak, 1993). In eastern Sheridan County, Montana, a water sample with a $\mathrm{CI}$ value greater than 0.035 is considered contaminated by brine (Reiten and Tischmak, 1993).

The Williston Basin has been a major source of domestic oil and gas production for the last 60 years, and the majority of brine contamination in surface water and shallow groundwater is related to legacy oilfield practices regarding the storage and disposal of brine (Murphy, 1983; Murphy and Kehew, 1984; Beal et al., 1987; Reiten and Tischmak, 1993; Thamke and Craigg, 1997). Brine contamination is generally related to point source releases near oil-field infrastructure and the most common sources are leachates generated from nowburied reserve pits that held drilling fluids and brine and are present at each oil and gas well (referred to as 'oil wells' from hereafter) site in the Williston Basin. Even after low viscosity fluids had been removed, the average reserve pit still contained a saline slurry with roughly 236 metric tons of salt when buried (Reiten and Tischmak, 1993). Soluble salts and exchangeable sodium ions are the most mobile 
constituents that leach from reserve pits, and also are the most detrimental to plants and soils (Mosley, 1983). These leachates migrate in the shallow groundwater system and can be discharged into nearby wetlands (Preston, 2011). In addition to reserve pits, other pathways exist for brine to enter the environment including: uncontained discharges (dumping), disposal well failures, corrosion of abandoned well casings, and breaks in pipelines that transport oil and brine to treatment and disposal facilities (Reiten and Tischmak, 1993; Thamke and Craigg, 1997; Preston, 2011).

Strategies for storage and disposal of brine in the Williston Basin have changed through time with the recognition of the environmental damage from reserve pits (Murphy and Kehew, 1984). Initial oil development occurred in the early 1950 's, and the majority of reserve pits were unlined. Additionally, many of these reserve pits were classified as evaporation pits, and would contain brine for several years until burial. Regulations were passed in the late 1970's that required the lining of reserve pits; however, many reserve pits were still reclaimed through a practice known as trenching into the late 1980's (Beal et al., 1987). In this now-abandoned practice, a backhoe was used to create unlined trenches away from the retired pit and the depression backfilled, forcing the contents to drain outward into the trenches. Although long lived evaporation pits likely release more leachates than trenched reserve pits, no barrier exists between the buried saline slurry and the underlying sediments in both situations. Currently, reserve pits in the Williston Basin and PPR are required to be lined with plastic and reclamation still relies on burial; however, the plastic liner is folded over the reserve pit and often a clay cap is used instead of the original earth material.

In 2009, the USGS formed the Science Team about Energy and Prairie Pothole Environments (STEPPE -http://steppe.cr.usgs.gov/) and began a multi-year study to evaluate the effects of historical and current oil and gas development in the Williston Basin and PPR. Part of this study investigated geologic controls on the migration of brine contamination by examining a study site in each of the three most common types of glacial deposits in the PPR (till, outwash, and lacustrine deposits). Analyses at these three detailed study sites included geophysical mapping of brine contaminated groundwater plumes, as well as major ion, trace element, and isotopic chemistry of surface water, shallow groundwater, and brine (Gleason et al., 2011; Preston, 2011; Preston et al., 2012; Peterman et al., 2012). Brine contamination was documented over $0.8 \mathrm{~km}$ in outwash deposits and over $0.4 \mathrm{~km}$ in glacial till deposits from the likely contaminant source (written commun. Bruce Smith, Research Geophysicist for the USGS Crustal Geophysics and Geochemistry Science Center, 5/1/2013). Based on data at two sites from the multiyear STEPPE study and two sites in Beal et al. (1987), there is a greater potential for contaminant migration in the coarse-grained outwash deposits relative to the clay-rich till.

Additionally, STEPPE researchers conducted a county-level geographic information system (GIS)-based vulnerability assessment of potential brine contamination to surface water and shallow groundwater resources from oil and gas development. This analysis was based on the number of oil wells, the number of wetlands, and the length of stream reach in each county of the Williston Basin. The objectives of the vulnerability assessment and sampling design described in this paper were to: 1 ) enhance the county-level GIS-based analysis by adding surficial geology and using a finer grid (approximately $2.59 \mathrm{~km}^{2}$ ) on the Public Land Survey System (PLSS) section level, and 2 ) validate the vulnerability assessment results by actively trying to locate contaminated aquatic resources within the sampled sections to determine the presence of brine contamination. The datasets used in the vulnerability assessment are available for the entire U.S.; therefore, this method could have regional applicability if it were conducted throughout the PPR of the Williston Basin.

Vulnerability assessments for groundwater contamination inherently contain uncertainties, but are useful for guiding decisions about groundwater (National Research Council, 1993). Regional-scale mapping of groundwater vulnerability commonly uses the index method
(Focazio et al., 2002). Important indices can be identified and quantitatively combined with different numerical scores and weights to include the relative importance of the physical attributes in influencing vulnerability, the natural variability, and the availability and spatial resolution of data. Obvious and documented indices such as oil-well age and density, surficial geology, and area and location of surface-water resources were selected for this study. The numerical scores and weights applied to these indices were developed by the authors and our STEPPE collaborators in order to conduct this vulnerability assessment and were based on past methods for the storage and disposal of brine and previous research regarding the migration of brine within the glacial deposits of the PPR.

\subsection{Study area}

The study area includes 780 PLSS sections (referred to as sections hereafter), or $2037 \mathrm{~km}^{2}$, in eastern Sheridan County, Montana. Due to the importance of including geological control on contaminant movement, the boundaries of this study were confined to the lateral extent of the surficial geology map of eastern Sheridan County published by Reiten and Tischmak (1993) and updated by Reiten in 2010 (Rouse et al., 2013). Oil and gas development began in the late 1950's and continues to the present (2013), with a total of 794 petroleum-related wells drilled in the study area at the time the analysis was conducted (February, 2011). The study area lies within the portion of the Williston Basin mantled by the PPR (Fig. 1), a broad area of till plain characterized by ice-decay features. Near-surface geology consists mainly of clay-rich glacial tills with lesser amounts of coarse-grained outwash deposits and fine-grained lacustrine deposits (Fullerton et al., 2004). The topography is generally rolling or hummocky with closed drainage systems, resulting in closed or poorly-drained basins and numerous wetlands (Martin and Hartman, 1987). Prairie wetlands are an ecologically recognized resource, providing critical habitat and breeding grounds for numerous wetland and grassland bird species (Batt et al., 1989). Within the boundaries of this study, the U.S. Fish and Wildlife Service (USFWS) manages 39 Waterfowl Production Areas (WPAs) as part of the Northeast Montana Wetland Management District.

\section{Materials and methods}

\subsection{Vulnerability assessment, site selection, and water sample locations}

The vulnerability assessment for potential brine contamination was based on five variables within each section: A) the date of the oldest oil well, B) the percent of surficial geology mapped as glacial outwash deposits, C) the percent of wetland cover, D) the total length of stream reach, and E) the total number of oil wells. ArcGIS 10 ModelBuilder was used to generate the vulnerability assessment score from four different spatial layers. The age and total number of oil wells were determined from the Montana Board of Oil and Gas's digital well database (http://bogc.dnrc.mt.gov/), downloaded in February 2011. The percent of glacial outwash was calculated from the surficial geology map of eastern Sheridan County provided by the Montana Bureau of Mines and Geology (Reiten, written commun., 2/15/2011, modified from Reiten and Tischmak, 1993) that was based on the soil survey of Sheridan County, Montana (U.S. Department of Agriculture, 1977), and later modified using the Soil Survey Geographic (SSURGO) Database (Soil Survey Staff, 2002). Percentage of wetland cover was obtained from the National Wetlands Inventory (U.S. Fish and Wildlife Service, 2009). Total length of stream reach was determined from the medium resolution National Hydrography Dataset (U.S. Geological Survey, 1999). Each section received a value for each of the five variables, with the final vulnerability assessment score calculated as $(\mathrm{A}+\mathrm{B}+\mathrm{C}+\mathrm{D}) \times \mathrm{E}$ (Table 1$)$. The values for each variable and the structure of the vulnerability assessment calculation were designed to create an equation in which the maximum possible score (112 from 
Table 1

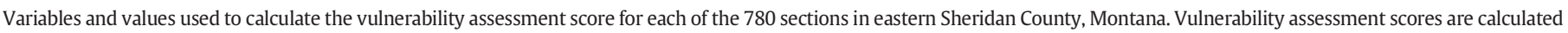
as $(A+B+C+D) \times E$.

\begin{tabular}{|c|c|c|c|c|c|c|c|c|c|}
\hline \multicolumn{2}{|l|}{ A } & \multicolumn{2}{|l|}{ B } & \multicolumn{2}{|l|}{$\mathrm{C}$} & \multicolumn{2}{|l|}{$\mathrm{D}$} & \multicolumn{2}{|l|}{$\mathrm{E}$} \\
\hline \multicolumn{2}{|c|}{ Oldest oil or gas well } & \multicolumn{2}{|c|}{$\%$ of glacial outwash (GO) } & \multicolumn{2}{|c|}{$\%$ of wetland $(\mathrm{W})$} & \multicolumn{2}{|c|}{ Stream reach $(\mathrm{SR})$} & \multicolumn{2}{|c|}{ Number of wells (NW) } \\
\hline Date & Value & $\%$ & Value & $\%$ & Value & Length (km) & Value & Number & Value \\
\hline Pre 1982 & 15 & $\mathrm{GO} \geq 75$ & 5 & $\mathrm{~W} \geq 75$ & 5 & $S R \geq 5$ & 3.0 & $\mathrm{NW} \geq 7$ & 4 \\
\hline 1982-1992 & 10 & $50 \leq \mathrm{GO}<75$ & 4 & $50 \leq \mathrm{W}<75$ & 4 & $4 \leq \mathrm{SR}<5$ & 2.5 & $3 \leq \mathrm{NW}<7$ & 3 \\
\hline \multirow[t]{4}{*}{ Post 1992} & 5 & $25 \leq \mathrm{GO}<50$ & 3 & $25 \leq \mathrm{W}<50$ & 3 & $3 \leq \mathrm{SR}<4$ & 2.0 & $1 \leq \mathrm{NW}<3$ & 2 \\
\hline & & $10 \leq \mathrm{GO}<25$ & 2 & $10 \leq \mathrm{W}<25$ & 2 & $2 \leq \mathrm{SR}<3$ & 1.5 & $\mathrm{NW}=0$ & 1 \\
\hline & & $\mathrm{GO}<10$ & 1 & $\mathrm{~W}<10$ & 1 & $1 \leq \mathrm{SR}<2$ & 1.0 & & \\
\hline & & & & & & $\mathrm{SR}<1$ & 0.5 & & \\
\hline
\end{tabular}

values $A=15, B=5, C=5, D=3$, and $E=4$ ) was weighted slightly more towards oil well characteristics (approximately $54 \%$ from values $\mathrm{A} \times \mathrm{E}=15 \times 4=60$ ) relative to the general site characteristics in areas with high densities of oil wells (approximately $46 \%$ for values $[B+C+D] \times E=13 \times 4=52$ ). It should be noted that sections without an oil well received a score of 5 for the oldest well score but the multiplier for the total number of wells was 1 , whereas the multiplier for any section containing an oil well(s) was 2,3 , or 4 depending on the total number of wells.

Based on the results of the vulnerability assessment and land ownership, ten of the 780 sections in the study area were selected to serve as detailed study sites for surface water and groundwater sampling. The vulnerability assessment scores for all 780 sections were binned into ten equal intervals, or ranks, from 1 to 10 (lowest to highest vulnerability to brine contamination) that represented similar probabilities of contamination. The section within each rank containing the greatest acreage of WPA land managed by the USFWS was then selected as the detailed study site for that rank to ensure consistent site access. All of the sampling locations were within the WPA boundaries and not necessarily distributed throughout the entire section.

As previously stated, the goal of this study was to validate the vulnerability assessment results by actively trying to locate contaminated aquatic resources; therefore, the locations of surface water and groundwater samples were from areas likely to be contaminated and not randomly selected. Surface water samples were collected from the two wetlands that contained water in the closest proximity to active or abandoned oil wells. Only one wetland contained water within the WPA boundary at sites ranked 3,8 , and 9 (Table 2), so both surface water samples were collected from different locations in the same wetland. Due to the high concentrations of DS present in brine, contaminated groundwater plumes often produce areas of high apparent conductivity in geophysical surveys. Therefore, placement of groundwater monitoring wells was determined by identifying active or abandoned oil wells on the land surface, conducting geophysical surveys with a Geonics EM-31 near these locations, and installing groundwater wells at locations with the greatest apparent conductivity measurements (for a through description of measuring electrical conductivity of soils and rocks, see McNeill, 1980). No active or abandoned oil wells were within the WPA boundary at sites with ranks of 1 (none in section), 2, 3, 6 (1 in each section), and 9 (11 in section); therefore, geophysical surveys were conducted along the WPA boundary nearest active or abandoned oil wells within the selected section and groundwater wells were installed in the areas of greatest apparent conductivity. Sediment type (till, outwash, or lacustrine) was generally consistent throughout the area surveyed with geophysical equipment. In the absence of existing monitoring wells at each study section, hydraulic gradients and groundwater flow directions were determined as following topographic gradients below the nearest oil well(s) in each section, except for the site ranked 1 which had no oil wells. The depth of groundwater wells (range 3.7 to $11.6 \mathrm{~m}$ ) was dependent on the depth to the water table (range 0.61 to $9.86 \mathrm{~m}$ ) and all wells were completed in the near surface glacial deposits.

It should be noted that there are some differences in how oil and gas development has occurred on WPA lands versus private land. A total of 1063 oil wells have been drilled in Sheridan County as of April 11th, 2013. Although oil drilling has been occurring continually since the 1950 's, there have been two major periods of development that currently (as of April 11th, 2013) account for over 60\% of the total number of oil wells; one spanning the 1960's when 292 wells were drilled and the other spanning the 1980's when 349 wells were drilled. Many of the WPA parcels in Sheridan County, Montana were acquired with the mineral rights in the late 1960's and early 1970's which was after the initial period of major development in the 1960's but before the second period of major development in the 1980's. Thus, while many of the older oil wells were already in place when these lands were acquired, the USFWS has worked with the energy industry to place newer oil wells further away from wetlands (pers. commun. Mike Borgreen, Wildlife Biologist at Medicine Lake National Wildlife Refuge, 3/21/2013). This is in contrast to private lands, where oil wells are often placed very close to wetlands to preserve farmable acreage. Since all the water samples were collected within WPA boundaries, they may represent areas with a possibly lower potential for brine contamination relative to private lands.

\subsection{Water sample collection and analysis}

Water samples were collected from groundwater monitoring wells and wetlands over a five-day period (8-12th) in September of 2011. Groundwater monitoring wells were purged until at least three well volumes of water were removed and parameters measured onsite ( $\mathrm{pH}$, water temperature, and specific conductance) had stabilized. Due to difference in yields from groundwater wells, groundwater samples were collected using a $5.1-\mathrm{cm}$ submersible pump, a peristaltic pump, a PVC bailer, or a disposable polyethylene bailer. Wetlands were sampled using a discrete sampling method modified from Knapton (1985). All of the wetland sites were shallow (typically less than $1.5 \mathrm{~m}$ deep) and previous studies in Sheridan County determined that these shallow wetlands are well mixed by wind-generated turbulence (Preston et al., 2012), so a single sampling location for each wetland was assumed to be representative of the entire wetland. Samples were collected by wading to as deep a location as possible, submersing four acid-rinsed polyethylene bottles (two each at $250 \mathrm{~mL}$ and 1-Liter) upwind of the sample collector, and removing the lids to fill the bottles.

Quality-control data to document the reproducibility of analytical results and any sample contamination were provided by test samples that consisted of either a replicate sample or a field-blank sample incorporated into the sample set. Quality-control samples comprised $20 \%$ of the total number of environmental samples submitted for analysis. Six unique replicate sample pairs were collected in the field by concurrently filling sample bottle sets with samples considered to be essentially identical in composition. Two field blanks were also collected. The field 
Table 2

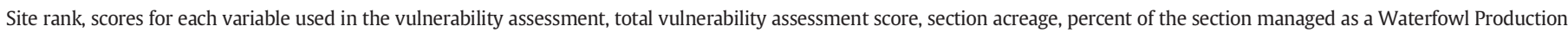
Area (WPA), and WPA name for each of the ten selected sections. See Table 1 for the distribution of values and equation used to calculate the vulnerability assessment score.

\begin{tabular}{|c|c|c|c|c|c|c|c|c|c|}
\hline Site rank & Oldest well score & $\%$ of glacial outwash score & $\%$ of NWI score & km NHD score & Number of wells score & Total score & Section area $\left(\mathrm{km}^{2}\right)$ & $\%$ of WPA & WPA name \\
\hline 1 & 5 & 3 & 5 & 0.5 & 1 & 13.5 & 2.59 & $59 \%$ & Parry \\
\hline 2 & 5 & 1 & 3 & 0.5 & 2 & 19.0 & 3.39 & $60 \%$ & State Line \\
\hline 3 & 5 & 5 & 3 & 0.5 & 2 & 27.0 & 2.59 & $34 \%$ & Big Slough \\
\hline 4 & 15 & 1 & 2 & 0.5 & 2 & 37.0 & 2.56 & $53 \%$ & Widgeon Slough \\
\hline 5 & 15 & 4 & 2 & 0.5 & 2 & 43.0 & 3.70 & $47 \%$ & Erickson \\
\hline 6 & 15 & 5 & 3 & 0.5 & 2 & 47.0 & 3.50 & $59 \%$ & Goose Lake \\
\hline 7 & 15 & 1 & 2 & 0.5 & 3 & 55.5 & 2.56 & $49 \%$ & North Root \\
\hline 8 & 15 & 4 & 2 & 0.5 & 3 & 64.5 & 2.57 & $47 \%$ & Rabenberg \\
\hline 9 & 15 & 1 & 1 & 0.5 & 4 & 70.0 & 2.58 & $13 \%$ & Ward \\
\hline 10 & 15 & 3 & 2 & 0.5 & 4 & 82.0 & 3.00 & $68 \%$ & Anderson \\
\hline
\end{tabular}

blanks were aliquots of deionized water that were processed through the same sampling equipment used to collect the environmental samples and subjected to the same processing as the environmental samples.

Sample processing, filtration, and preservation were performed in the field using methods described by USGS (variously dated). Samples were submitted to the USGS Strontium Isotope Laboratory in Denver, Colorado for analysis of major dissolved ions and selected halides using methods described by Fishman and Friedman (1989). Major dissolved ions were analyzed by Ion Chromatography (IC) following appropriate dilutions and use of standards in the range of the sample concentrations. Analytical uncertainty by IC is typically in the range of 5 to $10 \%$ of the reported value at the $95 \%$ confidence level.

\section{Results}

\subsection{Vulnerability assessment}

The calculated vulnerability assessment scores for all 780 sections within the study area ranged from 7.5 to 82 . These values were binned into ten equal interval ranks, with 1 being the lowest potential for brine contamination and 10 being the greatest. The section with the greatest acreage of WPA land in each rank was then selected for analysis. Fig. 2 shows the spatial distribution of the variables used in the vulnerability assessment, the resulting rank for each section, and the boundaries of WPAs within the ten sections selected for water sampling. The site rank, calculated vulnerability assessment score, and general information pertaining to the ten selected sections and WPAs are listed in Table 2. A total of 481 sections, or $62 \%$ of the study area, had low (1-3) vulnerability assessment ranks. Sections with an intermediate (4-6) vulnerability assessment rank totaled 203 and comprised $26 \%$ of the study area. A total of 96 sections, or $12 \%$ of the study area, had high (7-10) vulnerability assessment ranks.

\subsection{Water quality}

Specific conductance, chloride concentrations, and resulting $\mathrm{CI}$ values varied both within and across the ten selected sections (Table 3). The $\mathrm{CI}$ values indicated brine contamination $(\mathrm{CI}>0.035)$ at seven of the ten study sites and in 19 of the 40 total water samples. The $\mathrm{CI}$ values generally increase with increased site rank (Fig. 3), with this correlation being stronger for groundwater samples $\left(R^{2}=0.78\right)$ than surface water samples $\left(R^{2}=0.53\right)$. The $R^{2}$ values are from linear regressions fixed through the origin as the $\mathrm{CI}$ cannot produce negative values. Additionally, the $\mathrm{R}^{2}$ value for the surface water sites is calculated using the average $\mathrm{CI}$ value from wetlands 3,8 , and 9 as both surface water samples were collected from the same wetland.

For the six replicate sample pairs, the sample with the largest $\mathrm{CI}$ value is plotted in Fig. 3 and used for the calculation of $R^{2}$ values. The percent differences in major ion and trace element concentrations were within $10 \%$ for five of the six replicate sample pairs. In the sixth replicate sample pair, a groundwater monitoring well at Goose Lake WPA (site rank 6), the percent differences in major ion concentrations were much greater. The percent difference in chloride concentrations (6.37 and $9.62 \mathrm{mg} / \mathrm{L}$, respectively) was $41 \%$; while the percent difference in specific conductance values ( 1690 and $1680 \mu \mathrm{S} / \mathrm{cm}$, respectively) was less than $0.6 \%$. The calculated $\mathrm{CI}$ values for these two samples were 0.004 and 0.006 and both were well below the threshold of 0.035 that would indicate brine contamination. Although the replicate samples with the greater $\mathrm{CI}$ values are shown, using the replicate samples with the lower CI values only changes the $\mathrm{R}^{2}$ value for groundwater samples from 0.78 to 0.77 and does not affect the $R^{2}$ value for surface water samples.

\section{Discussion}

The use and relative weighting of the individual variables used in the vulnerability assessment were determined from historical oil-field practices, previous studies, and the expertise of STEPPE scientists and partners. The PLSS section was chosen as the sampling unit because the distance to the nearest oil well(s) is clearly important. The PLSS section grid is approximately $2.59 \mathrm{~km}^{2}$ and, in addition to providing a sampling unit that can be easily extended across the Williston Basin, limits the distance of the analysis to areas near the oil well(s) modeled. The dates 1982 and 1992 were selected to stratify the age of the oldest well as these are the earliest possible dates when reserve pit liners were commonly used and when trenching ceased, respectively. One of the primary goals of this project was to include surficial geology in the vulnerability assessment as the STEPPE project and previous studies (Beal et al., 1987) have shown that brine contamination can migrate further in coarse-grained glacial outwash deposits than clay-rich glacial till. The upper portion (top $6.1 \mathrm{~m}$ ) of glacial tills and lacustrine deposits in the PPR are often oxidized and vertically fractured which increases the hydraulic conductivity (Grisak and Cherry, 1975); however, glacial outwash deposits have a much greater hydraulic conductivity compared to unfractured and fractured till; $1.2 \times 10^{-7}-1.2 \times 10^{-3} \mathrm{~m} / \mathrm{s}$ compared to $1 \times 10^{-12}-1.2 \times 10^{-5} \mathrm{~m} / \mathrm{s}$, respectively (Schwartz and Zhang, 2003). Additionally, glacial till is the predominate deposit and much more prevalent than glacial outwash in the PPR (76.1\% and $10.4 \%$ in our study area, respectively) and the majority of oil wells are located in glacial till. Therefore, glacial outwash represents the geological deposit most conducive to brine migration in the PPR, and its inclusion in the vulnerability assessment incorporates the effect that geological controls have on the potential for brine contamination. The percent of wetland cover and total length of stream reach were selected to provide a metric for surface water resources. Scores for these four variables (age of the oldest oil well, percent outwash, percent wetland coverage, and length of stream reach) were summed together to produce an assessment of the general section characteristics. Finally, to encompass the cumulative impacts of multiple oil wells, the general section characteristic score was multiplied by a weighted multiplier that was based on the total number of oil wells. Other variables may affect the potential for 


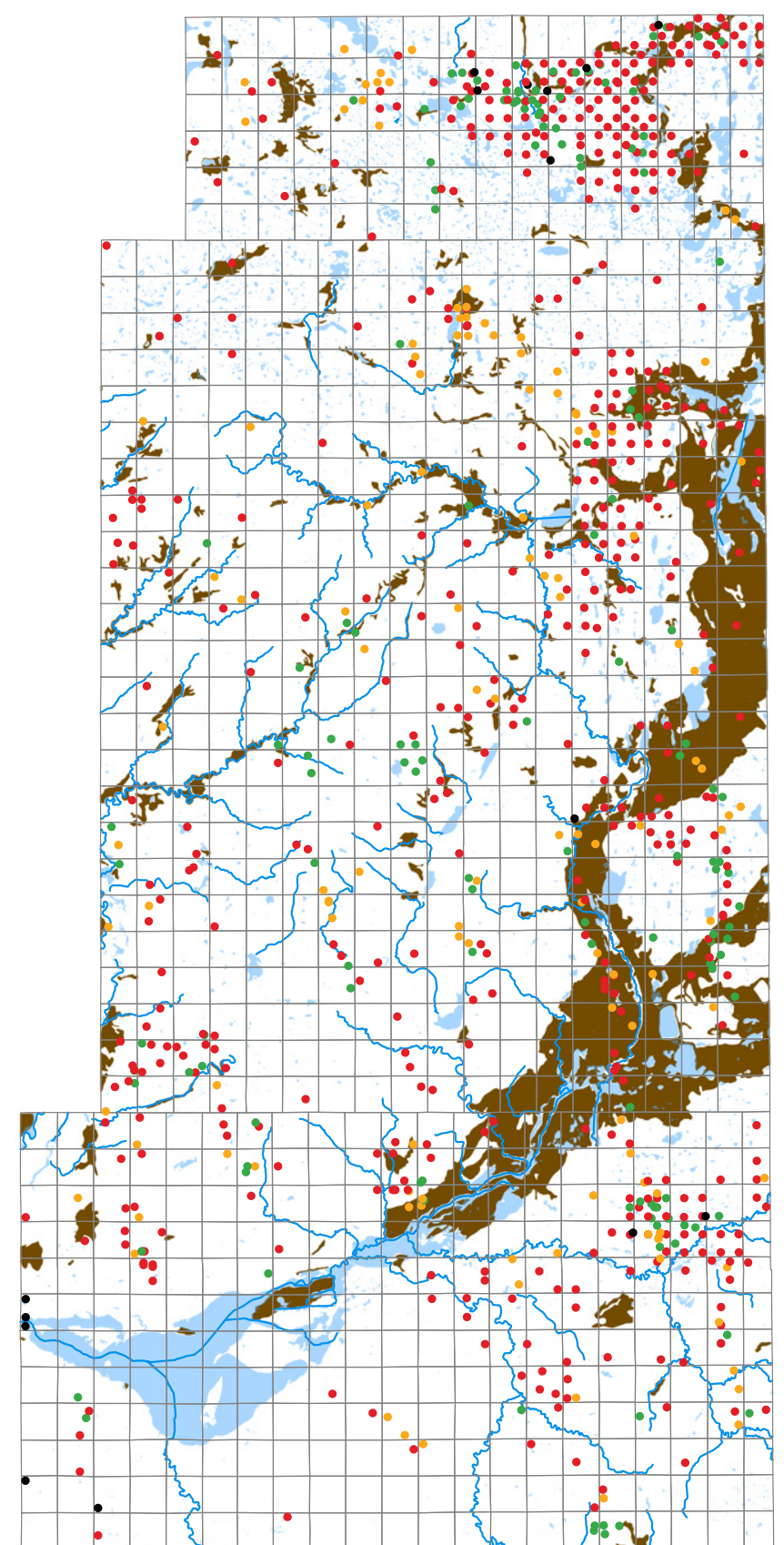

Oil Well Age Glacial Outwash
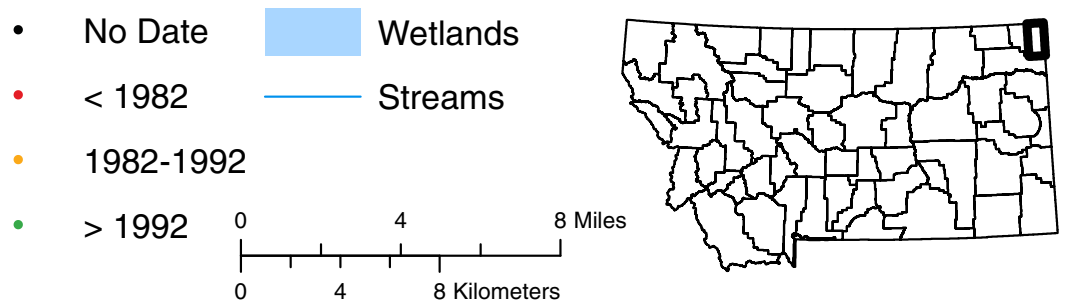
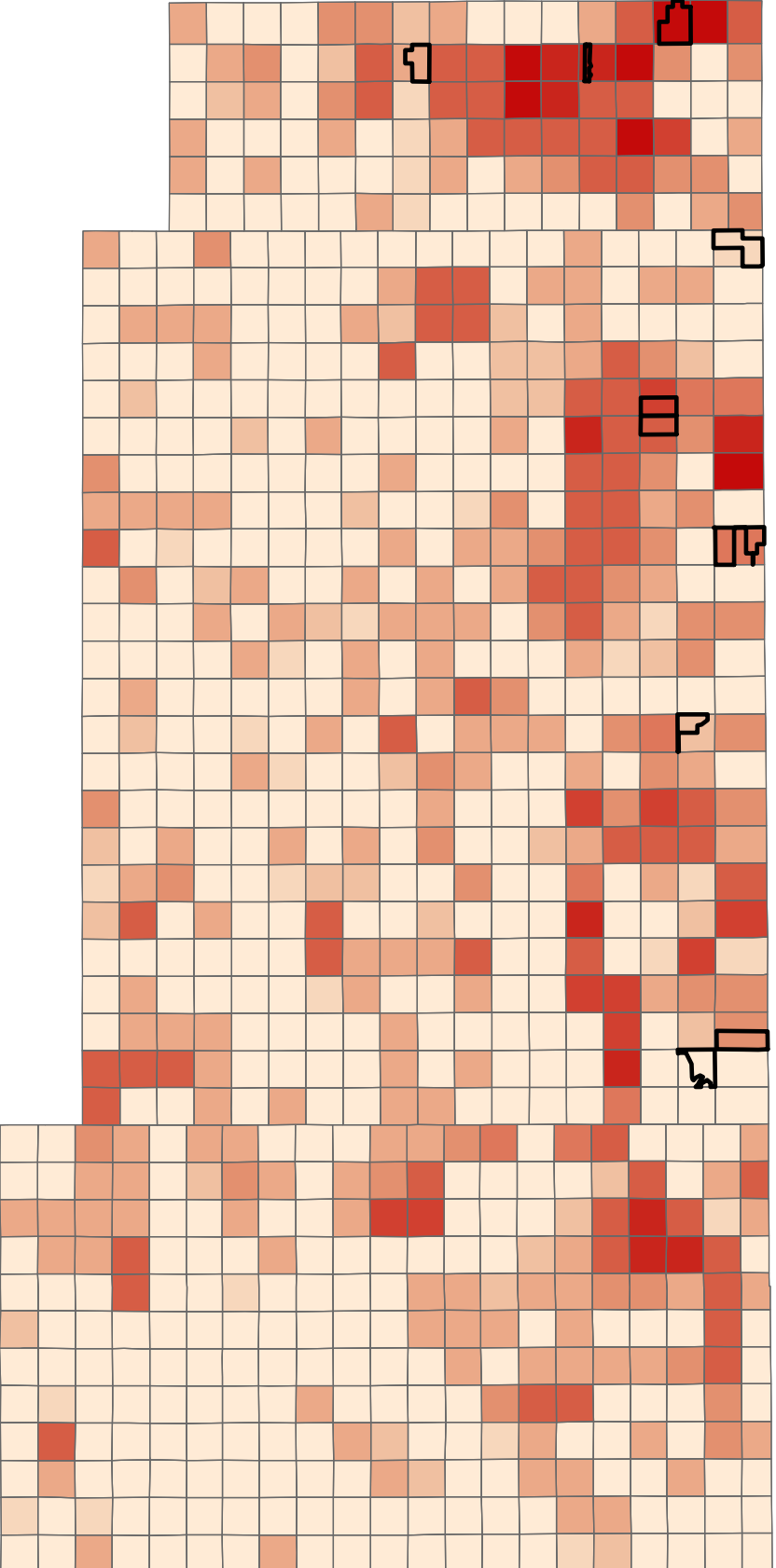

WPA Study Sites

\section{5}

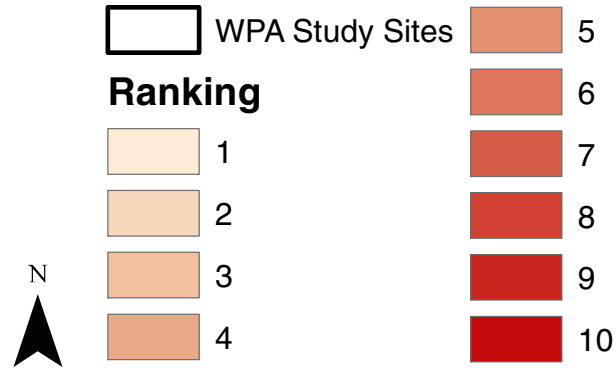

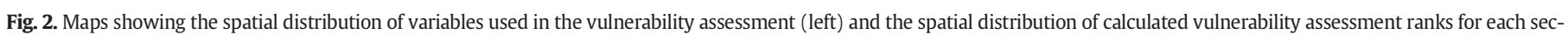
tion, locations of oil wells, and selected Waterfowl Production Areas studied (right), Eastern Sheridan County, Montana.

brine contamination; however, according to previous research, the five selected for this study are likely the most important.

The equation used to calculate the final vulnerability assessment score (Table 1 ) is weighted more towards the age of the oldest oil well and the total number of wells relative to the hydrogeological variables; however, the oil well variables alone are not the sole predictors of potential contamination to aquatic resources as evidenced by the total vulnerability assessment scores. To illustrate this point, Fig. 4 contains 
Table 3

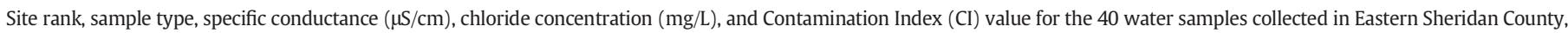
Montana.

\begin{tabular}{|c|c|c|c|c|c|c|c|c|c|}
\hline Site rank & Sample type & Specific cond. ( $\mu \mathrm{S} / \mathrm{cm})$ & Chloride conc. (mg/L) & CI value & Site rank & Sample type & Specific cond. ( $\mu \mathrm{S} / \mathrm{cm})$ & Chloride conc. (mg/L) & $\mathrm{Cl}$ value \\
\hline 1 & Well $^{\mathrm{a}}$ & 755 & 4.88 & 0.006 & 6 & Well $^{\mathrm{a}}$ & 1680 & 9.62 & 0.006 \\
\hline 1 & Well & 1430 & 9.80 & 0.007 & 6 & Well & 1800 & 12.3 & 0.007 \\
\hline 1 & Wetland & 4480 & 69.4 & 0.015 & 6 & Wetland & 2180 & 14.3 & 0.007 \\
\hline 1 & Wetland & 883 & 13.7 & 0.016 & 6 & Wetland & 5410 & 163 & 0.030 \\
\hline 2 & Well & 3700 & 18.1 & 0.005 & 7 & Well & 2210 & 264 & $0.119^{b}$ \\
\hline 2 & Well & 16,500 & 838 & $0.051^{\mathrm{b}}$ & 7 & Well & 41,200 & 15,000 & $0.364^{\mathrm{b}}$ \\
\hline 2 & Wetland & 3570 & 62.9 & 0.018 & 7 & Wetland & 300 & 0.55 & 0.002 \\
\hline 2 & Wetland & 11,000 & 316 & 0.029 & 7 & Wetland $^{\mathrm{a}}$ & 3950 & 465 & $0.118^{\mathrm{b}}$ \\
\hline 3 & Well $^{\mathrm{a}}$ & 1210 & 5.25 & 0.004 & 8 & Well & 11,700 & 3110 & $0.266^{\mathrm{b}}$ \\
\hline 3 & Well & 1130 & 9.26 & 0.008 & 8 & Well & 8900 & 3040 & $0.342^{\mathrm{b}}$ \\
\hline 3 & Wetland ${ }^{\mathrm{c}}$ & 3470 & 108 & 0.031 & 8 & Wetland ${ }^{\mathrm{c}}$ & 5380 & 1530 & $0.284^{\mathrm{b}}$ \\
\hline 3 & Wetland $^{\mathrm{C}}$ & 3470 & 110 & 0.032 & 8 & Wetland $^{\mathrm{c}}$ & 5320 & 1580 & $0.297^{\mathrm{b}}$ \\
\hline 4 & Well & 3490 & 125 & $0.036^{\mathrm{b}}$ & 9 & Well $^{\mathrm{a}}$ & 41,000 & 15,300 & $0.373^{\mathrm{b}}$ \\
\hline 4 & Well & 23,100 & 863 & $0.037^{\mathrm{b}}$ & 9 & Well & 36,700 & 15,000 & $0.409^{b}$ \\
\hline 4 & Wetland & 1220 & 39.8 & 0.033 & 9 & Wetland ${ }^{\mathrm{c}}$ & 453 & 21.4 & $0.047^{\mathrm{b}}$ \\
\hline 4 & Wetland & 26,100 & 894 & 0.034 & 9 & Wetland $^{\mathrm{c}}$ & 414 & 20.6 & $0.050^{\mathrm{b}}$ \\
\hline 5 & Well & 4710 & 110 & 0.023 & 10 & Well & 40,300 & 13,600 & $0.337^{\mathrm{b}}$ \\
\hline 5 & Well & 3220 & 107 & 0.033 & 10 & Well & 27,900 & 9960 & $0.357^{\mathrm{b}}$ \\
\hline 5 & Wetland & 9980 & 306 & 0.031 & 10 & Wetland & 2660 & 121 & $0.045^{\mathrm{b}}$ \\
\hline 5 & Wetland & 16,300 & 1280 & $0.079^{\mathrm{b}}$ & 10 & Wetland $^{\mathrm{a}}$ & 36,400 & 13,000 & $0.357^{\mathrm{b}}$ \\
\hline
\end{tabular}

a Replicate water sample pairs collected at this location.

b Indicates brine contamination.

c Both water samples collected from the same wetland.

boxplots of the distributions of total vulnerability assessment scores for each variable from all 780 sections (left column) and from the ten selected sections (right column). As can be seen from panels A1 and A2 (Fig. 4), sections with greater oldest well scores generally had greater total vulnerability assessment scores; however, the median vulnerability assessment score in panel $\mathrm{A} 1$ for the 289 sections with the maximum oldest well score (15) is only 38. This is less than half the maximum value (82) calculated from the vulnerability assessment, and demonstrates how the age of the oldest well alone is not sufficient to determine potential brine contamination. This is further supported by the fact that only one third (96) of these 289 sections had total vulnerability assessment scores above 52; the lowest bin range for sites with high vulnerability assessment ranks (7-10). Similarly, in panels E1 and E2 (Fig. 4), sections with greater scores for the total number of wells generally had greater total vulnerability assessment scores. However, only 13 of the 780 sections $(<2 \%)$ have the greatest possible score for the total number of wells (4) and of the 90 sections with the second largest score for the total number of wells (3), the median value was 55.5 (panel E1, Fig. 4); only slightly above the minimum value of the lowest bin with a high vulnerability assessment rank (52). Therefore, the total number of wells variable is also not sufficient to determine potential brine contamination by itself.

The hydrogeological variables (percent glacial outwash, percent wetland, and stream reach) are present across the landscape in areas with and without oil development; therefore, a larger score for any single variable would not be expected to produce a greater total vulnerability assessment score because the total score is heavily influenced by the presence and density of oil wells. This is indeed the case as can be seen in the boxplots for the hydrogeological variables in Fig. 4. With the exception of a modest increase in the median total vulnerability assessment score for sections with larger scores for the percentage of glacial outwash (panel B1, Fig. 4), there is no discernible trend in total vulnerability assessment scores associated with larger scores in the percentage of wetland cover (panel C1, Fig. 4) or the length of stream reach (panel
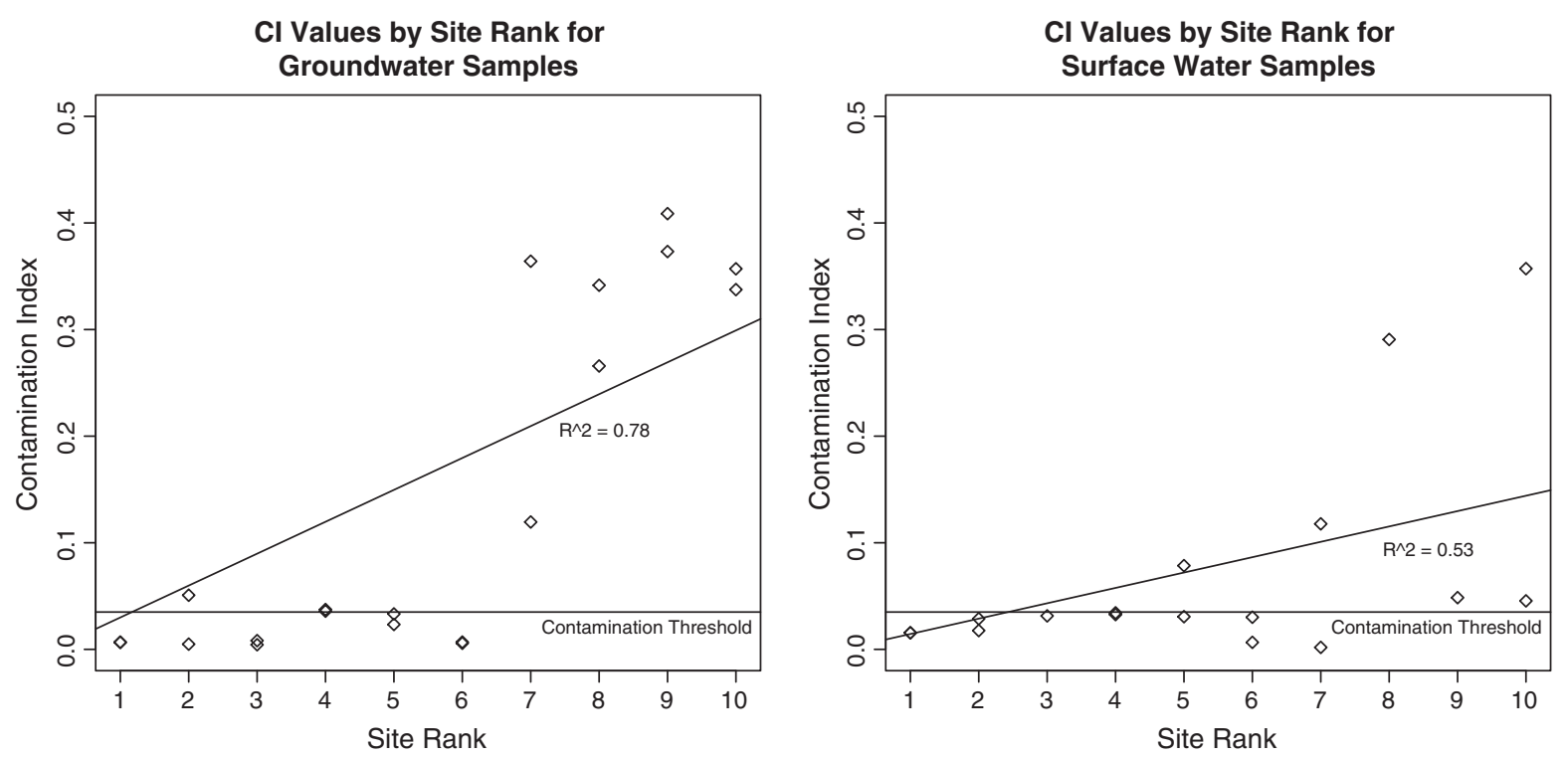

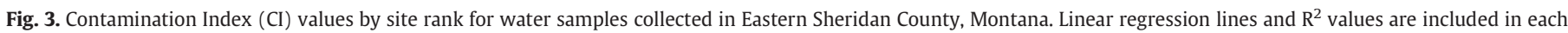
graph. Table 2 lists site rank and corresponding WPA names. Note: the value for the contamination threshold line is 0.035 as defined by Reiten and Tischmak (1993). 

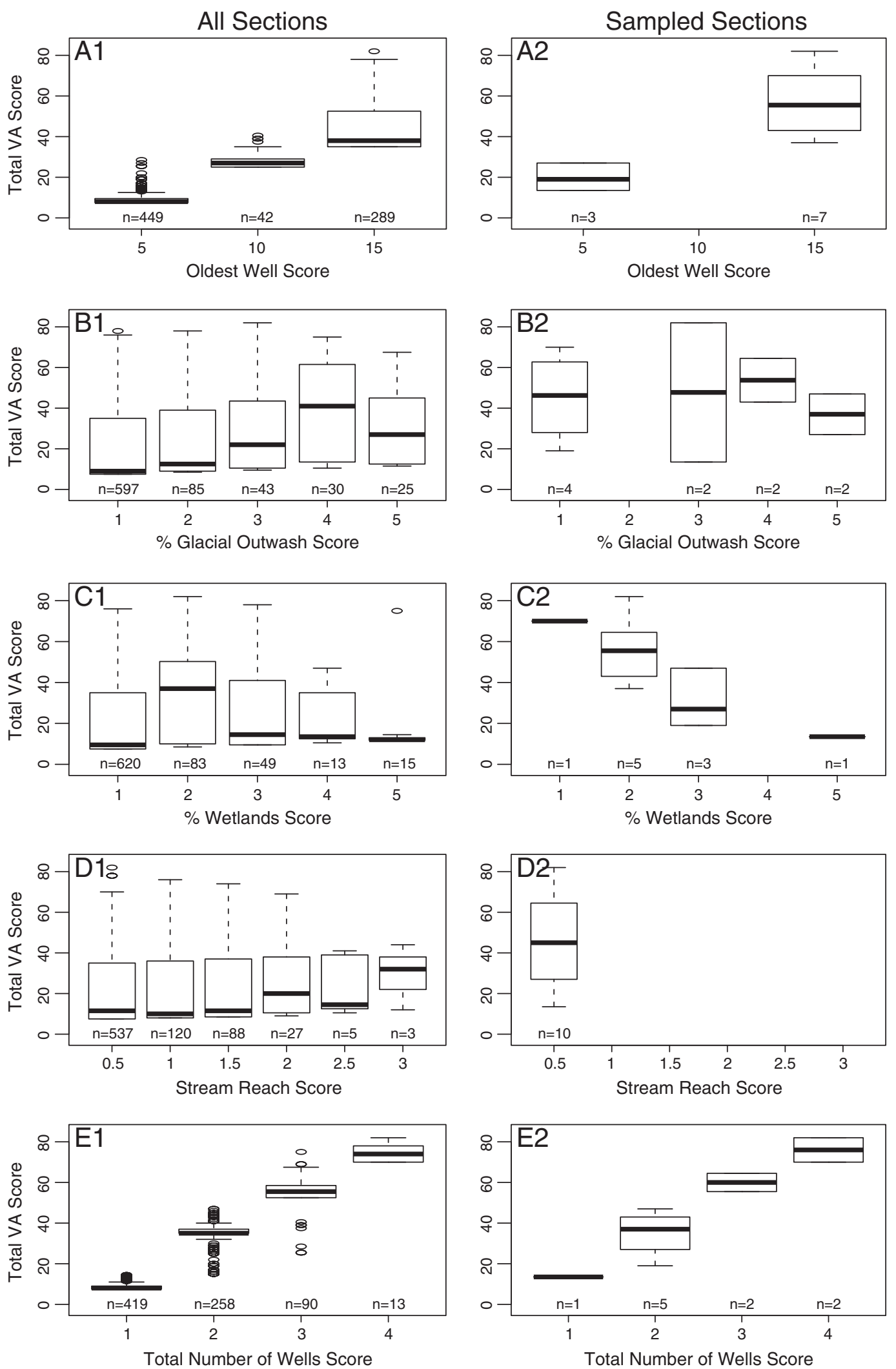

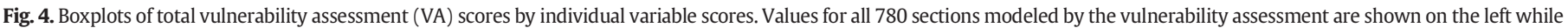
the ten sampled sections are shown on the right. Letters in the panels correspond to the variables in Table 1 (i.e. A1 and A2 are the boxplots for the age of the oldest oil well).

D1, Fig. 4). Additionally, the range of total vulnerability assessment scores from the hydrogeological variables (panels B1, C1, and D1, Fig. 4) is similar across most of the possible values for each individual variable and between the different variables. This further illustrates how these variables are not the drivers of the overall vulnerability assessment score, but rather enhances the analysis by identifying the 
areas with surficial geologic deposits most conducive to brine migration and/or areas with larger amounts of aquatic resources. Therefore, while the total vulnerability assessment score is highly influenced by the oil well variables, the hydrogeological variables incorporate the local environmental factors in each section and provide a stronger assessment of potential brine contamination to aquatic resources compared to using the oldest well and/or total number of wells alone.

Overall, the vulnerability assessment worked extremely well for sections with low (ranks 1-3) and high (ranks 7-10) scores; however, the assessment for sections with intermediate (ranks 4-6) scores was not as definitive. Only one of the 12 water samples from the three sites with a low vulnerability assessment score (panels 1-3 in Fig. 5) had a $\mathrm{CI}$ value indicating brine contamination (Table 3 and Fig. 3). This suggests that brine contamination is possible in sections with low vulnerability assessment scores (7.5-30), but is unlikely. In contrast, only one water sample (discussed below) of the 16 water samples from the four sites with high vulnerability assessment scores (panels 7-10 in Fig. 5) had a $\mathrm{CI}$ value that did not indicate brine contamination (Table 3 and Fig. 3). This implies that brine contamination is extremely likely, and probably widespread, in sections with a high vulnerability assessment score $(>52)$. In sections with intermediate vulnerability assessment scores (panels 4-6 in Fig. 5), three of the 12 water samples had CI values that indicated brine contamination; however, an additional five samples had $\mathrm{CI}$ values between 0.030 and 0.035 , or very close to the contamination threshold (Table 3 and Fig. 3). Two of the three contaminated samples were from Widgeon Slough WPA (site rank 4) and the remaining sample was from Erickson WPA (site rank 5). No water samples from Goose Lake WPA (site rank 6) indicated brine contamination. Thus, brine contamination is considered probable in sites with intermediate vulnerability assessment scores (30-52). While the vulnerability assessment did not perform ideally in the intermediately ranked sections, the low and high ranked sections (where the vulnerability assessment performed extremely well) cover approximately $74 \%$ of the study area and illustrate the value of using such an approach to model potential contamination from oil and gas development across large geographic areas.

The stronger correlation between site rank (or vulnerability assessment score) and $\mathrm{Cl}$ values for groundwater samples compared to surface water samples (Fig. 3) is likely due to differences in selecting sample locations, the proximity of sample locations to oil well sites, and being confined within the WPA boundaries. The goal of this study was to determine if brine contamination was present in the sections selected from the vulnerability assessment; therefore, we were actively trying to locate contaminated aquatic resources. To facilitate this goal, geophysical surveys were used to identify contaminated groundwater plumes based on the elevated apparent conductivities associated with highly saline brine. Groundwater wells were then installed where apparent conductivity measurements were greatest. In contrast, surface water samples were collected from the wetlands that contained water in closest proximity to oil well sites; thus, there was less control regarding the locations of these samples. As a result, groundwater samples generally were collected much closer to oil well sites than surface water samples. Finally, although the vulnerability assessment score was based on characteristics from the entire section, access was limited to only the portions of the sections within the WPA boundary and some wetlands and oil well sites used to calculate the vulnerability assessment score were inaccessible. Other factors, including the location of wetlands in relation to groundwater flowpaths and possible dilution of small amounts of brine in larger wetlands, may also account for some of the difference in correlations between surface water and groundwater samples; however, these are likely less important than the factors discussed above.

For example, the aforementioned issues are clearly illustrated at the North Root WPA (rank 7), which covers the north half of T36NR58ES34 (panel 7, Fig. 5). The two groundwater wells were installed in an area of high apparent conductivity emanating from the one oil well site in the
WPA. This resulted in the groundwater samples being collected in closer proximity to the oil well site compared to the surface water samples. Although this section had three oil wells installed prior to 1982, two of these are outside the WPA boundary, as is a large wetland. It would have been preferred to sample the large wetland outside the WPA, as it is close to and downgradient from an oil well site. Instead, the eastern wetland sampled in North Root is relatively far away from and upgradient of all the oil well sites in the section and is the only sample in sites ranked 7-10 that did not indicate brine contamination. Indeed, this sample had the lowest $\mathrm{CI}$ value and chloride concentration of any water sample ( 0.002 and $0.55 \mathrm{mg} / \mathrm{L}$, respectively).

Finally, there is currently a need for land managers to be able to quickly and easily identify areas with the greatest potential for contamination to aquatic resources from brine associated with oil and gas development across the Williston Basin. This GIS-based vulnerability assessment method could provide land managers with a cost-effective and science-based way to quantify areas with a high potential for brine contamination. Once high risk areas are identified, land managers can focus limited monitoring and reclamation funds to these areas. Additionally, such an analysis could be used to identify areas that require baseline water-quality data in relation to on-going oil and gas development. Our initial analysis in eastern Sheridan County, Montana, illustrates the successful applicability of using a GIS-based vulnerability assessment to examine potential brine contamination across a large geographic area.

\section{Conclusions}

We present a prototype PLSS section-level GIS-based vulnerability assessment to determine the potential for brine contamination to aquatic resources from oil and gas development in Eastern Sheridan County, Montana. The vulnerability assessment is based on the age of the oldest oil well, percent of glacial outwash deposits, percent of wetland area, length of stream reach, and the total number of oil wells in each section. Water chemistry results, namely CI values, from ten sections selected across the range of vulnerability assessment rankings generally validated the vulnerability assessment results; although there was a stronger correlation between the vulnerability assessment score and brine contamination in groundwater samples compared to surface water samples. However, the stronger correlation for groundwater samples compared to surface water samples is likely the result of differences in selecting water sample locations, proximity of water samples to oil well sites, and the requirement that water samples be collected within the WPA boundaries in the selected sections.

Water sample analytical results show the section level GIS-based vulnerability assessment did very well at identifying areas with high or low levels of brine contamination. Based on the $\mathrm{CI}$ value, only one of the 12 water samples from the three lowest ranked sections indicated brine contamination, whereas 15 of 16 water samples from the four highest ranked sections indicated brine contamination. Results from the three intermediate-ranked sections were not as definitive, with three of the 12 water samples indicating brine contamination. However, the low number of contaminated water samples is likely related to the issues described above.

These results validate the applicability of using this GIS-based technique across the entire U.S. portion of the Williston Basin overlain by the PPR. Such an analysis would provide land owners and managers with a science-based assessment regarding the potential for brine contamination to aquatic resources from oil and gas development. These results could then be used to allocate limited monitoring and reclamation funding, as well as identify areas in need of baseline water-quality data, in relation to on-going oil and gas development.

\section{Conflict of interest}

The authors have no conflicts of interest associated with this work. 

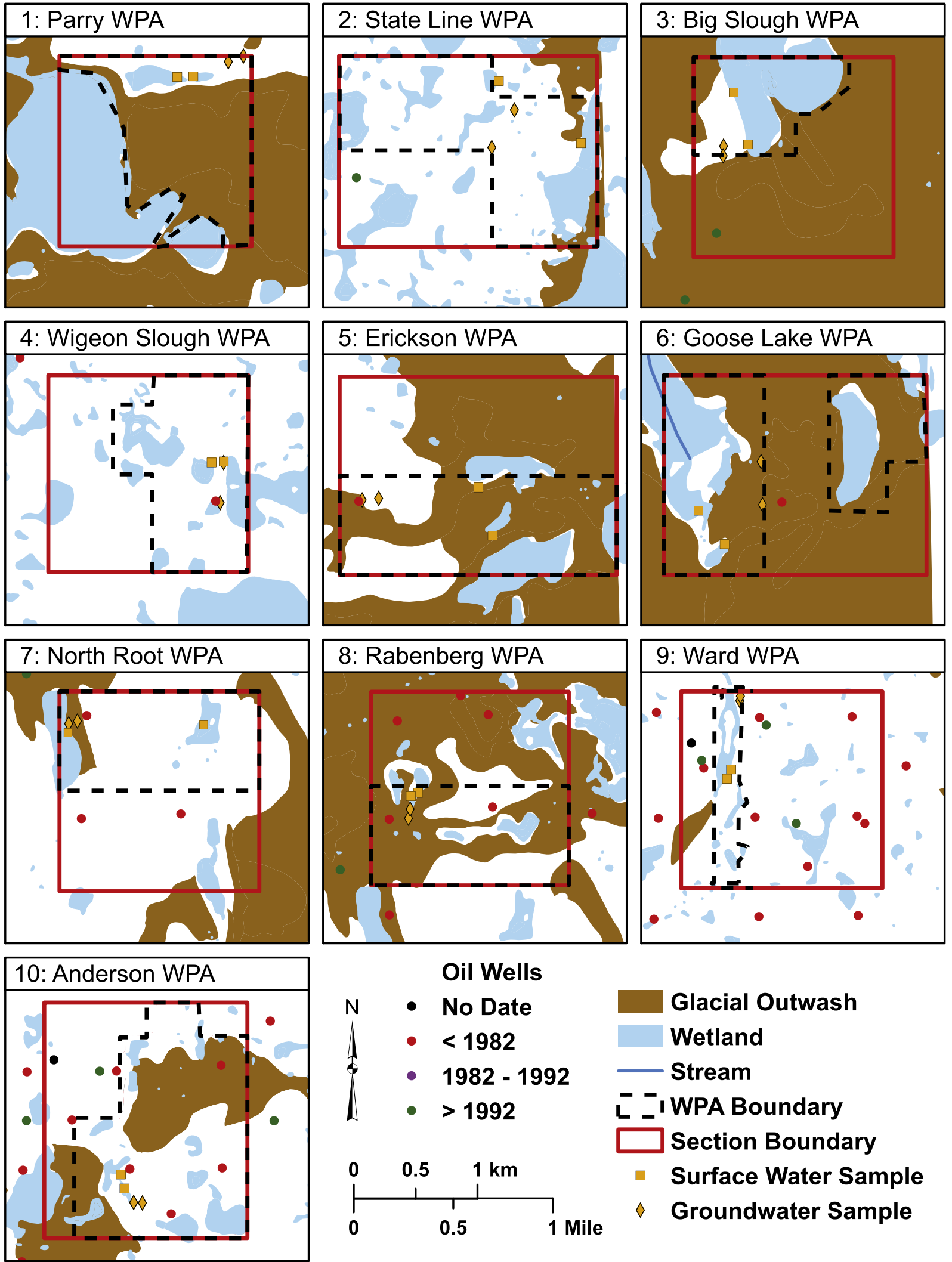

Oil Wells
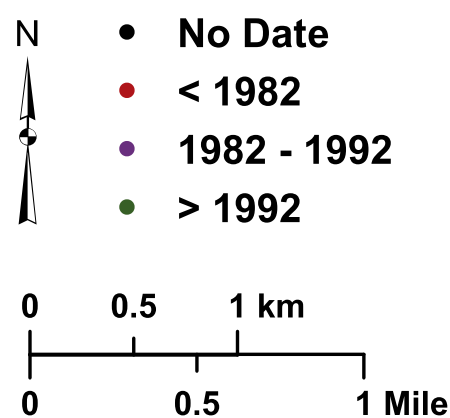

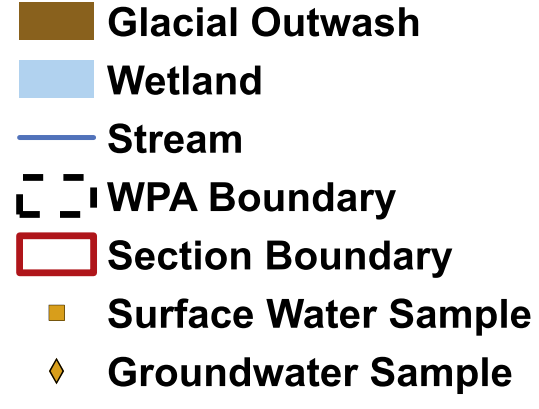

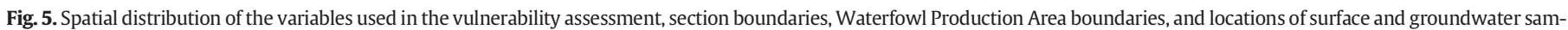
ples for the ten selected sites (panel number is site rank followed by WPA name).

Acknowledgments

Financial support for this work was provided by the U.S. Geological Survey State Partnership Program with in-kind funds provided by
Montana Bureau of Mines and Geology. The surficial geology map used in this analysis was prepared by Jon Reiten (Montana Bureau of Mines and Geology), who also provided technical assistance in developing the vulnerability assessment protocol. The authors also wish to 
thank Fred Bailey (USGS) for collection of surface water and groundwater samples, Zell Peterman and Thomas Oliver (USGS) for water quality analyses, and Jane Holzer, Scott Brown, and Tera Ryan (Montana Salinity Control) for installation of the groundwater monitoring wells. Any use of trade, product, or firm names is for descriptive purposes only and does not imply endorsement by the U.S. Government.

\section{References}

Batt BDJ, Anderson MG, Anderson DC, Caswell DF. The use of prairie potholes by North American ducks. In: van der Valk A, editor. Northern Prairie Wetlands. Ames IA: Iowa State University Press; 1989. p. 224-7.

Beal WA, Murphy EC, Kehew AE. Migration of contaminants from buried oil-and-gas drilling fluids within the glacial sediments of north central North Dakota. North Dakota Geological Survey, 86. Report of investigation; 1987. (43 pp.).

Fishman MJ, Friedman LC. Methods for determination of inorganic substances in water and fluvial sediments. U.S. Geological Survey Techniques of Water-Resources Investigations, book 5, chapter A1; 1989. (545 pp.).

Focazio MJ, Reilly TE, Rupert MG, Helsel DR. Assessing ground-water vulnerability to contamination: providing scientifically defensible information for decision makers. U S Geol Surv Circ 2002;1224. (33 pp.).

Fullerton DS, Colton RB, Bush CA, Straub AW. Map showing spatial and temporal relations of mountain and continental glaciations in the Northern Plains, primarily in northern Montana and northwestern North Dakota. Pamphlet to accompany U.S. Geological Survey Scientific Investigations Map; 2004. p. 2843.

Gleason RA, Chesley-Preston TL, Preston TM, Smith BD, Tangen BA, Thamke JN. Examination of brine contamination risk to aquatic resources from petroleum development in the Williston Basin. U.S. Geological Survey Fact Sheet 2011-3047; 2011. (4 pp.).

Grisak GE, Cherry JA. Hydrologic characteristics and response of fractured till and clay confining a shallow aquifer. Can Geotech J 1975;12:513-5.

Iampen HT, Rostron BJ. Hydrogeochemistry of pre-Mississippian brines, Williston Basin, Canada-USA. J Geochem Explor 2000;69:29-35.

Knapton JR. Field guidelines for collection, treatment, and analysis of water sampled, Montana District. U.S. Geological Survey open-file report; 1985. p. 85-409. (86 pp.)

LaBaugh JW, Winter TC, Adomaitis VA, Swanson GA. Hydrology and chemistry of selected prairie wetlands in the Cottonwood Lake Area, Stutsman County, North Dakota, 1979-82. U S Geol Surv Prof Pap 1987;1431. (26 pp.).

Martin DB, Hartman WA. The effect of cultivation on sediment composition and deposition in Prairie Pothole wetlands. Water Air Soil Pollut 1987;34:45-53.

McNeill JD. Electrical conductivity of soils and rocks. Geonics technical notes TN-5; 1980. (22 pp.).

Mosley HR. Summary of API onshore drilling mud and produced water environmental studies. IADC/SPE 1983 Drilling Conference, New Orleans, Louisiana, February 20-23, 1983; 1983. (5 pp.).

Murphy EC. The effect of oil and gas well drilling on shallow groundwater in western North Dakota. [M.S. Thesis] Grand Forks: University of North Dakota; 1983 (242 pp.).
Murphy EC, Kehew AE. The effect of oil and gas well drilling on shallow groundwater in western North Dakota. North Dakota Geological Survey report of investigations, 82. 1984. (156 pp.).

Murphy EC, Kehew AE, Groenewold GE, Beal WA. Leachate generated by an oil-and-gas brine pond site in North Dakota. Ground Water 1988;26:31-8.

National Research Council. Ground water vulnerability assessment, contamination potential under conditions of uncertainty. Washington, D.C.: National Academy Press; 1993 (210 pp.).

Peterman ZE, Thamke JN, Futa K, Oliver TA. Strontium isotope detection of brine contamination in the East Poplar oil field, Montana. U.S. Geological Survey open-file report 2010-1326; 2010. (20 pp.).

Peterman ZE, Thamke J, Futa K, Preston T. Strontium isotope systematics of mixing groundwater and oil-field brine at Goose Lake in northeastern Montana, USA. Appl Geochem 2012;27:2403-8.

Preston TM. Reexamining saline contamination associated with oil and gas development in the Prairie Pothole Region, Sheridan County, MT. [MS Thesis]Bozeman: Montana State University; 2011 (182 pp.).

Preston TM, Smith BD, Thamke JN, Chesley-Preston T. Water-quality and geophysical data for three study sites within the Williston Basin and Prairie Pothole Region. U.S. Geological Survey open-file report 2012-1149; 2012. (17 pp.).

Reiten J, Tischmak T. Appraisal of oil-field brine contamination in shallow ground water and surface water, eastern Sheridan County, Montana. Montana Bureau of Mines and Geology open file report 260; 1993 (296 pp.).

Rouse DR, Nelson KJ, Reiten JC. Montana-impacts of oil exploration and production to the northeast Montana Wetland Management District. Montana Bureau of Mines and Geology open file report 620; 2013 (264 pp.).

Schwartz FW, Zhang H. Geology and hydraulic Properties. Fundamentals of Groundwater New York, NY: John Wiley and Sons; 2003. p. 80.

Soil Survey Staff, Natural Resources Conservation Service, United States Department of Agriculture, Soil Survey Geographic (SSURGO) Database for northeastern Montana; 2002. Available online at http://soildatamart.nrcs.usda.gov.

Swanson GA, Euliss Jr NE, Hanson BA, Mushet DM. Dynamics of a Prairie Pothole wetland complex: implications for wetland management. In: Winter TC, editor. Hydrological, chemical, and biological characteristics of a Prairie Pothole Wetland Complex under highly variable climate conditions-the Cottonwood Lake Area, East-Central North Dakota, 1675. U.S. Geological Survey Professional Paper; 2003. p. 55-94.

Thamke JN, Craigg SD. Saline-water contamination in Quaternary deposits and the Poplar River, East Poplar oil field, northeastern Montana. U.S. Geological Survey Water Resources Investigations Report; 1997. p. 97-4000. (37 pp.)

U.S. Department of Agriculture Soil Conservation Service. Soil survey of Sheridan County. Washington D.C.: Montana; 1977 (60 pp.).

U.S. Fish and Wildlife Service. National Wetlands Inventory. Available online at http:// www.fws.gov/wetlands/Data/Data-Download.html, (Accessed1/9/2010).

U.S. Geological Survey. National Hydrography Dataset. Available online at: http://nhd. usgs.gov/, (Accessed 11/14/2009).

Wanty RB. USGS Research on saline waters co-produced with energy resources. U.S. Geological Survey Fact Sheet FS-003-97; 1997. (1 pp.). 